Shareholderism: Board Members' Values and the

Shareholder-Stakeholder Dilemma

\author{
RENÉE B. ADAMS \\ University of Queensland \\ UQ Business School \\ Brisbane QLD 4072, Australia \\ Tel: 61733657285 \\ Fax: 61733656988 \\ E-mail: r.adams@business.uq.edu.au \\ AMIR N. LICHT \\ Interdisciplinary Center Herzliya \\ Radzyner School of Law \\ Kanfe Nesharim St., Herzliya 46150, Israel \\ Tel: 97299527332 \\ Fax: 95299513323 \\ E-mail: alicht@idc.ac.il \\ (corresponding author) \\ LILACH SAGIV \\ Hebrew University of Jerusalem \\ School of Business Administration \\ Mount Scopus, Jerusalem 91905, Israel \\ Tel: 97226521841 \\ E-mail: mslilach@mscc.huji.ac.il
}

This version: 2 August 2009

Running Head: Shareholderism

JEL Codes: K22, M14

Keywords: corporate governance, stakeholders, corporate social responsibility, values 


\title{
Shareholderism: Board Members' Values and the
}

\author{
Shareholder-Stakeholder Dilemma
}

\begin{abstract}
This study investigates how personal values may affect strategic decisions of board members in dilemmas involving shareholders and other stakeholders. In a survey of the entire population of directors and CEOs in all public corporations in one country, we use vignettes that are based on seminal court cases to identify a general factor of shareholderism (vs. stakeholderism). Directors and CEOs exhibit greater shareholderism the more they endorse entrepreneurial values - namely, higher achievement, power, and self-direction values and lower universalism, benevolence, and conformity values. Employee representative directors exhibit more stakeholderist stances, but in most cases side with shareholders. Finally, directors in more profitable firms exhibit stronger shareholderism.
\end{abstract}


Few issues in the fields of strategy and corporate governance remain as contested as the topic of shareholders and stakeholders has been for so long. ${ }^{1}$ But while a great amount of research studied this issue from descriptive, instrumental, or normative perspectives (Donaldson \& Preston, 1995), fewer studies investigated the decisions of actual managers and no study to our knowledge has addressed this question at the level of the board of directors. Thus, the factors underlying the adoption of each approach by corporate elites (directors and top executives) remain unclear. There is no doubt that personal attributes of corporate elite members may influence their behavior and motivate organizational approach (Fiss \& Zajac, 2004; Hiller \& Hambrick, 2005). Strategic decision processes are further shaped by contextual factors, including aspects of both external and internal corporate environment (Papadakis, Lioukas, \& Chambers, 1998; Jensen \& Zajac, 2004). Understanding the factors that predispose a stakeholderist or shareholderist approach in board members would allow us not only to understand managers' decisions, but also to predict and influence them. This study investigates how managers' personal values, as well as their specific role, may direct their strategic decisions in stakeholder versus shareholder dilemmas.

That firms must strategically manage their relations with stakeholders has become common wisdom since Freeman's (1984) Stakeholder Theory. Recent analyses indicate a positive link between social and financial performance of firms (Barnett \& Salomon, 2006; Margolis, Elfenbein, \& Walsh, 2007; Orlitzky, Schmidt, \& Rynes, 2003; see also Godfrey, Craig, \& Jared, 2009; Choi \& Wang, 2009). But how do individual managers and board members confront these issues? Strikingly, based on a large survey of board members in S\&P400 firms, Lorsch and MacIver (1989: 49) found that directors may feel trapped in the traditional legal responsibility to shareholders and that board discussions "often resemble a

\footnotetext{
${ }^{1}$ See De Bakker, Groenewegen \& Den Hond (2005) for the historical development of these concepts.
} 
charade where directors, working toward the corporation's long-term interests, avoid revealing their standards and criteria or their deep belief in the need for a broad perspective."

We seek to identify these "standards and criteria" - the principles that comprise board members' "normative belief structure" (Fiss \& Zajac, 2004) and guide them in assessing firm strategy. Moreover, we propose to investigate what explains why some board members seek solely to maximize value for shareholders, whereas others also take into account the interests of other stakeholders, such as employees, consumers, and the community (what Easterbrook \& Fischel, 1991: 36 call "maximands"). Within the immense Stakeholder Theory literature, the vast majority of scholarship has dealt with the firm/organization level of analysis. Only a handful of studies have tried to investigate this question at the individual level of analysis that of the individual board member. Agle, Mitchell and Sonnenfeld (1999), for example, investigated whether personal values of American CEOs are linked to the salience of different stakeholders in their eyes. Their study, based on value items from Rokeach (1973), yielded mostly non-significant results. Shafer, Fukukawa, and Lee (2007) studied a somewhat related question: They found that values that reflect an emphasis on concern for others (i.e., universalism and benevolence values, based on Schwartz, 1992) are associated positively with ethical attitudes related to corporate social responsibility (CSR).

The present study advances a new theory on the factors that guide board members and top executives in strategic decisions that involve dilemmas between shareholders and other stakeholders. We investigate both personal (e.g., values) and contextual (e.g., professional role) factors that affect board members' orientations and decisions in shareholders/stakeholders dilemmas. Specifically, we hypothesize that corporate elite members will endorse corporate actions that benefit shareholders the more they emphasize entrepreneurial values, as these values emphasize wealth attainment, competitiveness, and venturing, consistent with shareholders' entrepreneurial role in the firm. They will endorse 
actions that benefit stakeholders the more they emphasize universalism values, as these values reflect concern and care for all people. We further hypothesize that board members representing a particular non-shareholder constituency (employee representatives) are more likely to exhibit stances that balance the interests of several constituencies as a general matter because their role calls on them to make such deliberations.

To test our theory we conducted a survey of board members in Sweden. Sweden is a useful laboratory for such a study for several reasons. Unlike in many other countries, it is possible to survey the entire population of directors of all public corporations. Directors' duties under Swedish law are similar to those under U.S. and U.K. law. Finally, a special feature of Swedish corporate governance - the presence of union-appointed directors on the board - allows one to investigate role effects and possible consequences of board composition. However, because we utilize a universal model of personal values, our results are in no way limited to Sweden.

We find that emphasizing self-enhancement values and (to a lesser extent) openness to change values and de-emphasizing self-transcendence values may lead to supporting a general stance of shareholderism (vs. stakeholderism). Values explain directors' shareholderism above and beyond other personal characteristics, including the role on the board, gender, and age. Values' explanatory contribution is robust to firm-level attributes such as size and financial performance.

Our study makes several contributions to the research on strategic management and corporate governance. First, we theorize and generate hypotheses about stakeholders in a new theoretical framework with universal applicability. Second, we cover for the first time the entire population of board members in public corporations in a country thus limiting concerns with sample selection. Third, we investigate the top echelon of decision-makers in firms, which has been under-researched notwithstanding its crucial role in strategy formation 
and corporate governance. Fourth, we assess likely responses to realistic shareholderstakeholder dilemmas by using vignettes based on seminal court cases. Fifth, we provide first evidence on likely consequences of employee representation on the board.

\section{THEORY AND HYPOTHESES}

\section{Values, Entrepreneurship, and the Shareholder-Stakeholder Dilemma}

Values are defined as conceptions of the desirable that guide the way individuals select actions, evaluate people and events, and explain or justify their actions and evaluations (Kluckhohn, 1951). Values are trans-situational criteria or goals, ordered by importance, that serve as guiding principles in one's life (Rokeach, 1973; Schwartz, 1992). Values affect the way people perceive and interpret the world around them (e.g., Gandal et al, 2005; Sattler \& Kerr, 1991; Schwartz, Sagiv \& Boehnke, 2000; Van Lange \& Liebrand, 1989), their identity (Hitlin, 2003), and ultimately, their decisions, choices, and behavior (Meglino \& Ravlin, 1998; Rockeach, 1973; Verplanken \& Holland, 2002). Researchers have documented relationships between values and behavior (e.g., Bardi \& Schwartz, 2003; Barnea \& Schwartz, 1998; Caprara et al., 2006; Feather, 1995; Grunert \& Juhl, 1995; Sagiv \& Schwartz, 2004). Importantly, Verplanken \& Holland (2002) showed that these relations are causal - that values lead to actions consistent with them. When experimental manipulations activated central values in subjects' memory, these values predicted value-relevant behavior.

To operationalize values, we use Schwartz's (1992) theory. Based on universal requirements of human existence, Schwartz identified ten basic motivations and derived ten values that represent them (see Table 1). Actions taken in the pursuit of a certain value carry social, psychological, and practical consequences that might conflict or may be compatible with the pursuit of other values. This pattern of conflict and compatibility among the ten values represents a circular motivational continuum. The closer any two values, the more compatible their underlying motivations; the more distant, the more antagonistic their 
motivations. The distinctiveness of the ten values and their structural relations have been verified in the vast majority of more than 200 samples from over 65 countries. This supports using the Schwartz theory as a universal model of human motivations (see Hitlin \& Piliavin, 2004; Rohan, 2000; Schwartz, 2007 for reviews).

The relationships between the ten values can be summarized in two basic conflicts: self-enhancement vs. self-transcendence and openness to change vs. conservation. Selfenhancement values focus on self-interests through the pursuit of control over people and resources (power) and of competence and success (achievement). These values conflict with self-transcendence values that reflect concern for close others (benevolence) and for all people and nature (universalism). Openness-to-change values reflect openness to what is new: excitement and novelty (stimulation) and autonomy of thought and action (selfdirection). These values conflict with conservation values that reflect a strong preference to preserve the status quo through a commitment to past beliefs and customs (tradition), adherence to social norms and expectations (conformity) and stability for self and close others (security). Hedonism values share elements of both openness to change and selfenhancement.

Efforts to anchor the study of managerial values in psychological theory are relatively recent (e.g., Agle \& Caldwell, 1999; Meglino \& Ravlin, 1998). With regard to stakeholders, Mitchell, Agle, and Wood (1997) propose that managerial values concerning self-interest or self-sacrifice may moderate the stakeholder-manager relationship by affecting stakeholder legitimacy. Hemmingway (2005; Hemingway \& Maclagan, 2004) conjectures that championing CSR depends on values that reflect a sense of duty to society (see also Schneider, Oppegaard, Zollo, \& Huy, 2005). As noted above, empirical evidence on the role of values is scant and undecided (see Agle, Mitchell, \& Sonnenfeld, 1999; Shafer, Fukukawa, 
\& Lee, 2007). ${ }^{2}$ Extant theory thus refers to self-interest versus other-regarding motivations, which map onto Schwartz's self-enhancement/self-transcendence dimension. This is in line with advances in behavioral economics that substantiate the existence of other-regarding motivations (Sobel, 2005; DellaVigna, 2008; see Bosse, Phillips, \& Harrison, 2008 in connection with stakeholders).

Because values are trans-situational goals that guide people in assessing actions in terms of legitimacy and desirability, it stands to reason that they also operate when board members are called to pass judgment on the corporation's long-term interests. Values thus may be the "standards and criteria" mentioned by Lorsch and MacIver (1989), on which board members draw to assess corporate strategy; values may be the constitutive elements of corporate elites' normative belief structures postulated by Fiss and Zajac (2004). Directors will tend to view the best interests of the firm and endorse strategies consistently with their values.

We concur with the view that a multiple-maximand corporate governance is premised on a view of many societal members as constituencies whose welfare deserves consideration. We believe, however, that it is not necessary to anchor a monist, shareholder-focused corporate governance in selfishness. After all, astute stakeholder management need not be against anybody's interest, including shareholders, as the recent evidence suggests. A broad other-regarding concern for multiple stakeholders is especially reflected in universalism as the motivation to understand, accept, and care for other people (whether familiar or not) and for humanity. It is also consistent (though to a lesser extent) with benevolence, which reflects the motivation to help familiar others in one's in-group. In the corporation, these may be the employees. In contrast, a shareholder wealth maximization view is consistent

\footnotetext{
${ }^{2}$ More remotely, in a sample of mid-level U.S. managers, Tetlock (2000) found that political conservatism positively predicted a preference for a monist, shareholder-focused corporate philosophy and negatively for a pluralist, stakeholder-oriented philosophy.
} 
with emphasizing power and achievement values. These values reflect the motivation for wealth attainment and control over others (power) and for success in competitive settings through hard work, self-challenging, and persistence (achievement). These goals are promoted by a focus on maximization of profits and share price as indicators for wealth and success, in line with shareholder interest. We therefore hypothesize:

H1: Support for shareholder wealth maximization will correlate positively with power and achievement and negatively with universalism and benevolence value priorities.

To better understand the motives underlying shareholder- versus stakeholder-oriented strategies, we advance a new, more general theory that links corporate strategy to directors' values through the notion of entrepreneurship. From an economic theory perspective, equity investors are the firm's entrepreneurs (Jensen \& Meckling, 1976; Bitler, Moskowitz, \& Vissing-Jurgensen, 2005). From the legal perspective, shareholders do not have any fixed claim on the corporation. Coupled with limited liability, this leads to shareholders having an interest that firms take up new projects with uncertain outcomes, as the rewards from innovation accrue to them (Kraakman et al., 2004). We therefore propose that more entrepreneurial decision-makers will tend to endorse strategies that benefit the entrepreneurial constituency in the firm, namely, shareholders.

In economic theory, the willingness to bear uncertainty and upset the equilibrium is precisely the quality that distinguishes entrepreneurs from other economic actors (Knight, 1921; Kirzner, 1973). Schumpeter (1934: 93-94) put forward the iconic profile of the entrepreneur and of entrepreneurial motivations:

First of all, there is the dream and the will to found a private kingdom, usually, though not necessarily, also a dynasty... The sensation of power and independence loses nothing by the fact that both are largely illusions... Then there is the will to conquer: the impulse to fight, to prove oneself superior to others, to succeed for the sake, not of the fruits of success, but of success itself... Finally, there is the joy of creating, of getting things done, or simply of exercising one's energy and ingenuity... Our type [the entrepreneur] seeks out difficulties, changes in order to change, delights in ventures. This group of motives is the most distinctly antihedonist of the three. 
Drawing on these accounts of entrepreneurship, Licht (2007) recasts the entrepreneurial spirit in terms of motivational goals as one high on power and achievement values as well as on self-direction and stimulation. Noseleit (2008), using a large dataset from several countries, finds consistent evidence among European entrepreneurs and nonentrepreneurs (see Fagenson, 1993 for further evidence).

In the entrepreneurial values theory, board members assess corporate strategy in light of the full set of their personal values, including values on the openness-tochange/conservation dimension. Directors whose values are more entrepreneurial in the sense just described will emphasize the entrepreneurial aspect of the firm and thus endorse strategies that benefit shareholders. The present theory thus subsumes hypothesis $\mathrm{H} 1$ as set forth above, emphasizing the broad Schumpeterian conception of power and achievement and de-emphasizing universalism. Maximizing profits and share price (as well as market share and firm size) are all consistent with the entrepreneurial will to found a kingdom, to conquer, to succeed for the sake of success, etc. In addition, emphasizing self-direction and stimulation is in line with the famous Schumpeterian "creative destruction" - the unsettling of things in order to make new combinations - and in line with shareholders' interest, as the latter enjoy limited liability. The latter implies:

H2: Support for shareholder wealth maximization will correlate positively with selfdirection and stimulation value priorities.

\section{The Institutional Setting and Social Roles}

Swedish corporate law is similar to the law in the U.S. and the U.K. in prescribing that the purpose of business corporations is to generate profits for shareholders. This widelyaccepted doctrine is deduced from a provision requiring companies with a different objective to state this clearly in the articles of association (Swedish Companies Act 2005, Ch. 3., Sec. 
3). The board of directors has the authority to propose an allocation of profits to the decision of the general meeting and thus controls distribution, including of dividends. Under the listing rules of the Stockholm Stock Exchange, firms with market value higher than SK 3 billion must adopt the Swedish Code of Corporate Governance (Code Group, 2005). This Code focuses on meeting the owners' required return on capital; it does not deal with relations with customers, employees, or the general public. These matters have not been considered part of corporate governance (p.12).

Starting in 1973, Swedish law prescribes for board representation for employees. Employees, through their trade unions, have the right to appoint two directors in companies with more than 25 employees and three directors in companies with more than 1,000 employees. Employee representatives may not constitute a majority on the board. The trade union branches usually appoint representatives for regular workers and for white-collar workers (Victorin, 2000). A survey of Swedish CEOs ("managing directors" in Swedish parlance) reflects a positive experience with employee representation on company boards (Levinson, 2001). Appointed by the board of directors, the CEO is the only senior executive sitting on the board in most listed companies in Sweden, beyond employee-appointed representatives. All other board members are non-executive directors, yet only a few directors are independent of the major shareholders (Code Group, 2005).

The setting of this study allows us to derive a hypothesis about likely effects of board members' roles (see Jensen \& Zajac, 2004; cf. Ibrahim, Howard, \& Angelidis, 2003). Employee representative directors do not negotiate with the management at arm's length; they are not adversaries to the firm. Rather, their assessment of the firm's best interests likely is affected by their having to consider multiple vantage-points: of their constituents, of shareholders (e.g., competitiveness and profitability), and of other stakeholders. Crucially, we aver that employee representative directors will not focus solely on employees' interests. 
Rather, we hypothesize that these directors will tend to side with stakeholders in general because their role in the firm calls on them to make such multi-focal considerations. Hence:

H3: Employee representatives on the board will side with non-shareholder constituencies more than other board members.

\section{METHODS}

\section{Sample and Data Collection}

We identified the entire population of directors, CEOs and vice-CEOs (the equivalent of presidents in U.S. firms) of all publicly-traded firms in Sweden in 2005 using MM Partner, a database containing data on all public and private firms in Sweden and their board members. There were 288 publicly-traded firms listed on the OMX Nordic Exchange and the Nordic Growth Market (NGM) in 2005. These firms had 424 CEOs (including Vice-CEOs) and 1372 resident board members.

We sent a survey questionnaire comprising scales on personal values, need for cognitive closure, and corporate governance together with a cover letter from the authors describing the study. In total, we received 502 responses $(36.6 \%)$ from board members - an unusually high response rate for this type of participants. Of those, 127 were employee representatives $(71 \%$ male, mean age $=53)$ and 375 were regular board members $(83 \%$ male, mean age $=57)$. We received 126 responses $(29.7 \%)$ from CEOs and Vice CEOs $(96 \%$ male, mean age $=51)$. We received at least one response for 252 of 288 firms $(88 \%)$. The number of responses per firm varies from 1 to 8 .

\section{Measures}

\section{Shareholderism versus Stakeholderism}

Empirical investigation of managers' support for shareholder versus stakeholder interests (shareholderism versus stakeholderism) ideally would examine managers' actual behavior in real shareholder-stakeholder conflicts. Collecting a sufficient sample for such an 
inquiry is virtually infeasible, however, because each organization faces the shareholder/stakeholder dilemmas in different circumstances. It would be impossible to compare across organizations should we look at actual behavior.

To measure CEOs and board members decisions we therefore employ a quasiexperimental approach using vignettes on shareholder-stakeholder conflicts. Vignettes are widely used in social science research (McFadden et al., 2005), and have also been used to gauge managers' ethical values (Barnett \& Karson, 1987; 1989). Vignettes provide the researcher "a degree of uniformity and control over the stimulus situation approximating that achieved by researchers using experimental designs" (Alexander \& Becker, 1978: 93). When properly used, vignettes can be useful for investigating participants' judgment-making processes and the factors that influence their decision-making (Alexander \& Becker, 1978; Barter \& Renold, 1999; Finch, 1987). Vignettes should appear plausible and real; they should strike a balance between providing sufficient context while leaving enough room for several reasonable solutions (Barter \& Renold, 1999; Wason, Polonsky, \& Hyman, 2002).

We take a novel approach by deriving our vignettes from seminal cases from the United States and the United Kingdom. Consultations with several Swedish corporate law professors indicated that these cases would likely be decided similarly in Sweden. Specifically, the vignettes are based on the following cases.

1. Consumers - Dodge v. Ford (1919) - Thanks to its dominant position in the automobile industry the Ford Motor Company had a very large surplus fund. Henry Ford wanted the firm to use these funds in a way that would benefit consumers (and also employees). The court held that "[a] business corporation is organized and carried on primarily for the profit of the stockholders. The powers of the directors are to be employed for that end."

2. Employees - Parke v. Daily News (1962) - A U.K. newspaper publishing company suffered substantial trading losses. To avoid further losses, the board decided to liquidate 
the company's assets and pay its employees and pensioners beyond their legal entitlements in order "to alleviate the suffering and hardship which may occur." The court held that the proceeds should be distributed to shareholders.

3. Creditors - Credit Lyonnais v. Pathé (1991) - MGM was in financial distress following a leveraged buyout. In a famous footnote to the main ruling, the court averred that "at least where a corporation is operating in the vicinity of insolvency, a board of directors is not merely the agent of the residue risk bearers, but owes its duty to the corporate enterprise;" the board may decline to accept a "fire sale" price for a corporate asset to finance dividends, thus helping creditors.

4. Community - Shlensky v. Wrigley (1968) - The company that owned the Chicago Cubs baseball club and operated its Wrigley Field stadium refused to approve installation of lights and night baseball because Phillip Wrigley believed that baseball was a day-time sport and that night baseball might have a negative impact on the surrounding neighborhood. The court held for Wrigley notwithstanding lower attendance and financial losses.

5. Corporate Philosophy - This vignette asks respondents to indicate which of the two corporate philosophies, copied verbatim from Tetlock (2000), they would support for posing on the firm's website: a single-maximand shareholder-oriented corporate philosophy or a multiple-maximand stakeholder-oriented philosophy.

The vignettes presented to the participants included no reference to their origin nor actual information such as names or industry of the company involved. Consistent with the original cases, each vignette specified two propositions, one favoring shareholders and one favoring the non-shareholder constituency. It deserves emphasizing, that like the original cases, the vignettes represent true dilemmas in that there was no "third way" which would benefit all the parties involved, at least in the long run, or could avoid harm to one of the parties. Such 
cases might not come up on a daily basis. But it is precisely this quality which makes the original legal cases seminal - because board members, and the court, were truly between a rock and a hard place. They had to endorse a strategic move that would benefit one party at the expense of the other, while being exposed to potential liability or scrutiny.

For each vignette, participants reported their agreement with each proposition on a 6point scale ranging from "strongly agree" to "strongly disagree". ${ }^{3}$ The corporate governance questionnaire was translated from English to Swedish and then back-translated using native speakers. Discrepancies were clarified by consulting with the authors.

\section{Personal Values}

To measure personal values we use the 40-item Portrait Values Questionnaire (PVQ) instrument developed by Schwartz (Schwartz et al., 2001). Schwartz kindly provided us with a Swedish version of the PVQ (available from the authors). To control for differences in scale use when correlating values with external variables we center each individual's scores around their mean (Schwartz, 1992; 2007). Internal reliabilities (alphas) of nine value indexes ranged from .59 to .83 . Bearing in mind that values are particularly broad constructs, these reliabilities are well within the range of variation commonly observed for values (Schmitt, Schwartz, Steyer, \& Schmitt, 1993). The index for tradition exhibited an unacceptable $\alpha=.34$. Nevertheless, tradition correlated systematically well in further analyses (see below). ${ }^{4}$

Personal values are best measured by self-reports (Schwartz, 1992). Similarly, behavioral intentions in the face of organizational strategic dilemmas can only be measured by self reports (see above). We followed Podsakoff et al.'s (2003) recommendations for minimizing common method variance by using temporal and methodological separation of

\footnotetext{
${ }^{3}$ In analyzing the data we reversed the scale so it is more intuitive to the reader.

'In addition to data on value priorities we also collected data on board members' need for cognitive closure using an instrument based on Kossowska et al. (2002).
} 
measurement. In analyzing the data we further followed Podsakoff et al.'s recommendations by partialling out respondents' general tendency for scale-use, a procedure that further minimizes common method response bias.

\section{Control Variables}

We control for particular roles, or governance positions, held by some board members, namely, employee representative and CEO. We also control for several individuallevel variables: age, gender, length of tenure on the board, and the number of other directorships held by the respondent in public firms. Corporate elites' governance positions may imply different agency contexts and together with demographic characteristics may affect corporate strategy (Jensen \& Zajac, 2004). We also control for three firm-specific variables: $\log$ of firm size, $\log$ of total firm-level wages, and profitability. Firm size could relate to managers' shareholderism stances indirectly, e.g., more consideration of other stakeholders may be required in smaller firms. We use the book value of assets to proxy for firm size. After controlling for firm size, firms' higher expenses on wages may reflect greater importance for labor in the firm. More remotely, it might reflect greater pressure on directors to consider non-shareholder stakeholders. Firm operating performance could affect shareholderism stances since more profitable firms may have more "slack resources" at their disposal for catering to stakeholders (e.g., Waddock \& Graves, 1997), though current evidence suggests that financial performance and social performance may not be mutually exclusive (see Barnett \& Salomon, 2006; Margolis, Elfenbein, \& Walsh, 2007; Orlitzky, Schmidt, \& Rynes, 2003). We use return on assets, an accounting-based measure to proxy for firm performance. Table 2 provides summary statistics. 


\section{ANALYSIS AND RESULTS}

\section{Shareholderism and Stakeholderism}

We first seek to verify whether the common broad distinction of "shareholders vs. stakeholders" is borne out in our data. Specifically, we examine whether the five vignettes represent the same content world, and whether shareholderism and stakeholderism are best represented by one bi-polar dimension. An exploratory factor analysis with oblique rotation (promax) yielded three factors. Pairs of items measuring shareholders/stakeholders views in each vignettes always loaded on the same factor (in opposing directions), indicating that shareholderism/stakeholderism views are two poles of the same dimension. All but the two creditor items loaded on the first factor, accounting for $32.7 \%$ of the variance. The two creditor items loaded on the second factor. None of the items had its primary loading on the third factor. An 8-item index yielded satisfactory reliability $(\alpha=.77)$. We averaged these eight items to construct a shareholderism (vs. stakeholderism) index. This index captures an ideological spectrum about corporate strategy and corporate governance that scholars have assumed for decades and now receives empirical validation for the first time. The two creditor items were dropped from further analyses (see the discussion).

We now turn to a detailed investigation of responses to the vignettes. Since Swedish boards are heterogeneous by legal design, we compare three groups: regular board members, board members who are employee representative directors, and CEOs. Figure 1 presents means and standard deviations of participants' responses to the vignettes. The findings reveal that participants form two camps: regular directors' and CEOs' average scores do not differ in order on any item, whereas employee representatives differ from the former two groups on all items. In all four vignettes, employee representative directors favored stakeholders' interests more and shareholders' interests less than did board members of the other two groups. We conducted a multivariate analysis of variance (MANOVA) with the type of 
group as the independent variable and the shareholder/stakeholder preferences as the dependent variables. The three groups differed on all but the creditors items (F ranges from 5.74 to 155.48 , all $\mathrm{p}<.001)$. A series of planned contrasts revealed significant differences between the employee representative board members and each of the two other groups for all but the creditors items ( $\mathrm{t}$ ranges from 2.69 to 18.15 , all $\mathrm{p}<.01$ ).

A richer picture emerges from considering particular cases. When shareholders' interests were contrasted with the interests of employees (Panel A of Figure 1), regular board members and CEOs sided with shareholders whereas employee-representatives naturally sided with the employees. When shareholders' interests were contrasted with the interests of the community (Panel B) and of consumers (Panel C), all three groups of participants favored shareholders' interests, albeit by a significantly narrower margin for the employee representatives. A surprising consensus emerged with regard to the item on a general corporate philosophy (Panel D). Members of all three groups rejected the shareholder wealth maximization philosophy in favor of the multiple-stakeholder philosophy. Employee representatives again sided with the stakeholders view more than the other two groups.

These findings indicate that decisions in shareholders-stakeholders dilemmas are associated with contextual factors: Board members who are employee representatives favor stakeholders' interests more than board members of the other two groups, thus fully supporting hypothesis $\mathrm{H} 3$. At the same time, the nature of dilemma in question also affects the decisions: When asked about their general philosophy, members of all three groups preferred a more stakeholderist view - even if only for declaratory purposes - but when presented with specific dilemmas they tended to favor shareholders' interests.

The results shed new light on the relations between the law and the reality of strategic decision-making in board rooms. When faced with concrete cases, the majority of board members, including employee-appointed directors, would act in line with the legal 
prescription. In fact, Swedish directors would side with shareholders even in cases where the U.S. court in Shlensky sided with stakeholders (the community). Swedish directors also share the shareholderist stance exhibited by the U.K. court in Parke with regard to employees, unlike their counterparts on the board of the Daily News. A substantial portion of all types of board members nonetheless would side with non-shareholder stakeholders.

Notwithstanding the legal prescription, however, board members of all types would strongly prefer to post a multiple-stakeholder corporate philosophy on the firm's website than a shareholder-value philosophy. This finding extends Fiss \& Zajac's (2004) argument that firms may engage in decoupling by espousing but not implementing a shareholder value orientation ( $c f$. Westphal \& Zajac, 2001). Here, a substantial group of individual board members would have their firm espouse but not implement a multiple-stakeholder orientation.

\section{Shareholderism and Values}

We now turn to testing our hypotheses linking support for shareholderism or stakeholderism to personal value priorities. As a first approximation, Table 3 presents correlations between shareholderism stances and value priorities in our sample. A clear pattern emerges. Corporate fiduciaries are more likely to exhibit a shareholderist stance the more they emphasize power and achievement and the less they emphasize universalism and benevolence, in line with Hypothesis H1. With somewhat lower yet significant correlations, shareholderism correlates positively with self-direction and stimulation and negatively with conformity and tradition, in line with Hypothesis H2. When we separately looked at the three sub-samples, $\mathrm{H} 1$ receives support in all sub-samples but $\mathrm{H} 2$ only among employee representative directors. At the same time, regular board members and CEOs score significantly higher on self-direction and stimulation than employee representatives do. We return to this question in the regression analysis. 
These findings are generally consistent with the notion that shareholderism goes hand in hand with endorsing more entrepreneurial values. Interestingly, shareholderism exhibits a near-zero correlation with hedonism. Self-gratification appears to play virtually no role in shaping corporate fiduciaries' stances in CSR-related dilemma. This finding is particularly noteworthy in light of Schumpeter's assertion, that entrepreneurial motivations have little to do with hedonistic incentives.

\section{Testing the Full Model}

Next, we conducted a regression analysis to investigate the contribution of value priorities, board members' roles, other personal demographics, and firm-level factors to predicting shareholderism. Differences in value priorities have been observed with regard to age and gender: older people exhibit increased emphases on conservation and selftranscendence values and decreased emphases on openness-to-change and self-enhancement (Schwartz, 2007; see also Glen, 1974); men tend to attribute more importance to power, stimulation, hedonism, achievement, and self-direction and less importance to benevolence and universalism, but these differences are usually quite small (Schwartz \& Rubel, 2005). It is thus important to control for these individual attributes.

Schwartz's model predicts that value priories are linked conceptually and empirically. This feature could cause problems in a regression analysis due to multi-collinearity. We therefore first employed the Stepwise procedure to identify those values that contribute significantly to the regression model. ${ }^{5}$ When all values were entered to the stepwise regression analysis, power, achievement, self-direction, and universalism contributed significantly and were thus included in the regressions below. Because many firms have more than one respondent we adjust standard errors for within-firm correlation across

\footnotetext{
${ }^{5}$ The forward stepwise model selection procedure begins with an intercept-only model and sequentially adds variables - starting with the variable with the lowest p-value - as long as their inclusion contributes significantly to the sum of squares.
} 
directors by clustering them at the firm level. We also use robust standard errors to adjust for heteroskedasticity.

Table 4 presents the regressions. Column 1 shows regression results of shareholderism stances on the four values. All values exhibit (standardized) coefficients largely equal in size, with the signs predicted by Hypotheses $\mathrm{H} 1$ and $\mathrm{H} 2$, in line with the entrepreneurial values theory. This specification alone explains $21 \%$ of the variance.

In the next step, we investigate whether shareholderism is particularly pronounced among board members who are simultaneously high on all the motivations that constitute the Schumpeterian entrepreneurial spirit - namely, high power, achievement, and self-direction. To examine this, we constructed an interaction term, which is the product of the average of power and achievement scores times the self-direction score. ${ }^{6}$ This entrepreneurship interaction term indeed associates positively with shareholderism (column 2). This term becomes non-significant in the more elaborate specifications, however.

In column 3, we focus specifically on the role of employee representative and its contribution to explaining shareholderism with a view to testing Hypothesis H3. It is important to test $\mathrm{H} 3$ in a regression setting because value priorities and roles may be confounded. Entering a dummy variable for employee representative position $(1=$ employee representative) yields a strong, negative coefficient indicating that these board members are in general less shareholderist than regular board members and CEOs, in line with Hypothesis H3. These results indicate that including board position in the regression addresses an important omitted variable bias. In tandem, power, universalism, achievement, and selfdirection continue to predict shareholderism significantly, though less strongly for the latter two values. We separately confirmed that F-statistic and R-squared rise significantly with the

\footnotetext{
${ }^{6}$ We use these three values in light of the Stepwise regression results mentioned above. Power and achievement represent the self-enhancement/self-transcendence dimension and self-direction represents the openness-tochange/conservation dimension in the Schwartz (1992) model. Subtracting universalism from power and achievement in the interaction term yielded similar results.
} 
inclusion of board position. Employee representative position explained an additional $16 \%$ of the variance beyond values.

In column 4 we enter the full set of personal attributes in addition to the values variables and employee representative position: CEO position $(1=\mathrm{CEO})$, gender $(1=$ male $)$, age, tenure, and the number of directorships. Values and holding an employee representative position remain significant predictors for shareholderism. Holding a CEO position does not have a significant role in predicting shareholderism relative to regular directors. Male board members are significantly more shareholderist even while accounting for values, board position, etc. Older directors are less shareholderist than younger ones. Both tenure and the number of directorships associate positively with shareholderism. This is consistent with the idea that dominant shareholders may prefer to nominate shareholderists to more boards and to keep them longer on the board. These personal attributes together explain an additional $4 \%$ of the variance beyond values and employee representative position. ${ }^{7}$

Finally, in column 5 we enter firm-level attributes - return on assets, size, and total wage bill. ${ }^{8}$ Only financial performance exhibits a significant positive coefficient. (Controlling instead for return on equity, a laxer measure of performance, did not yield a significant result). Directors in more financially profitable companies tend to be more shareholderist in their attitude. This finding, which is beside the main focus of the present study, is intriguing nonetheless, as we elaborate below. Entering industry dummies yielded similar results for values and board position but not for profitability.

\footnotetext{
${ }^{7}$ The results are robust to including additional personal characteristic controls such as wealth.

${ }^{8}$ For directors who sit on the board of more than one firm in our sample we enter firm-level data of a random firm. As a robustness test we computed and entered the average firm-level characteristics for every director with multiple board seats in our sample. This specification is consistent with the notion that responses to vignettes may reflect the average experience from all the boards on which one sits. We also ran a regression of all director-firm observations in our sample $(\mathrm{N}=775)$. This specification might be interpreted as imputing the particular firm-level characteristics to the firms mentioned in the vignettes. The results in both tests were similar to those presented.
} 
The results thus show that personal values and board members' role each have a substantial contribution to predicting shareholderism stances among corporate elite members. These findings provide a much necessary individual-level foundation for any discussion about firm-level strategy or firm-, or national-, level corporate governance. Better understanding "what makes a director tick" is essential for such discussions, be they descriptive, instrumental, or normative (Donaldson \& Preston, 1995).

Obviously, values and roles do not exhaust the factors affecting stakeholder-related issues (as the results indicate, too). Beyond the inevitable limitations of the quasiexperimental approach, one might wonder whether values cause board members to adopt certain shareholderism stances. If values are endogenous in the above regressions, in the sense that they are correlated with the error term, one cannot give these regressions a causal interpretation. We nonetheless believe that such an interpretation is plausible. Endogeneity typically arises because of reverse causality or omitted variables. In our context it is difficult to imagine that shareholderism stances would affect values by way of reverse causality. Extant evidence indicates that people's values develop at an early age (Goodnow, 1997; Knafo \& Schwartz, 2004), which makes it unlikely for shareholderism to feed back to values. What about possible endogeneity between values and roles? The variance in value profiles of individuals of different professions appears to stem in large part from selection (Gandal et al., 2005). Individuals with a value profile that is consistent with the "job description" of caring about shareholders or for employees are more likely to apply to, be nominated for, and retained in the respective positions (see Schneider, Goldstein, \& Smith, 1995). The result for shareholderism, tenure and directorships lend preliminary support to this view. We recognize, therefore, that shareholderism and employee representative role may be endogenous in the regressions in that shareholderists would be less likely to be 
employee representatives and vice versa. However, while we hesitate to infer causality from this particular result, we believe that the correlation is what is important in this case.

Even if values are largely predetermined or at least stable, our coefficient estimates could still be biased if there is an omitted variable that is correlated both with values and with shareholder stances. The analyses reported above greatly alleviate this concern, too. That the values variables retain a significant role in the regressions suggests that values explain shareholderism stances above and beyond their role due to personal attributes. The general scheme of these results is consistent with the notion that values are among the channels through which board position, gender, and age exert their influence on directors' shareholderism stances.

\section{DISCUSSION}

Ever since the seminal debate between Dodd (1932) and Berle (1932) over the question "For whom are corporate managers trustees?", much of the decades-long discussion on CSR has assumed that companies and managers can be told, or taught, how to behave "responsibly," whether this entails solely maximizing shareholder wealth or also catering to other stakeholders' needs. ${ }^{9}$ In many cases, managers are left to their own devices when they face CSR-related dilemmas. We expand the theoretical underpinnings for understanding the role of values in strategic decisions on stakeholders as we derive a new theoretical account that draws on a full set of values. We argue that in situations calling for such decisions, managers are likely to resort to values - their stable beliefs and goals - as criteria for guidance on the right behavior.

Agle and Caldwell (1999) decry the confusion in prior work on the role of values in business, which they partially attribute to "lax operationalization of the values construct."

\footnotetext{
${ }^{9}$ See Bradley, Schipani, Sundaram, \& Walsh (1999); Licht (2004) for surveys. For treatments in the economic literature see Adams \& Ferreira (2007); Berglöf \& von Thadden (2000); Bertr\& \& Mullainathan (2003); Faleye, Mehrotra, \& Morck (2006); Pagano \& Volpin (2005).
} 
Our study addresses this challenge. First, we operationalize personal stances on CSR using a quasi-experimental approach that relies on real court cases, which was verified to be relevant for Swedish corporate governance. This represents a radical departure from the common approaches that seek to measure corporate social performance (CSP) or use hypothetical ethical dilemmas. Instead of looking at aggregates of firm-level indicators we trace the roots of CSR/CSP at the individual level of board members. Second, we leverage a theory of values that has been validated to reflect a universal structure of individual-level values, together with an advanced instrument for measuring personal value priorities. Third, the present theoretical framework highlights the role of values such as self-direction on the conservation/openness-to-change dimension, which has been overlooked in the literature thus far. Thanks to the universality of the analytical framework, the basic findings of this study are generalizable beyond Swedish directors and corporate governance.

The recent results from meta-analyses notwithstanding, scholars and managers alike still debate whether companies can "do good and do well" at the same time. Framing the debate in this way implicitly pits shareholders against the rest of society. Moreover, by classifying corporate actions in the interest of non-shareholder stakeholders as "social responsibility" - Friedman (1970) being a famous exception - this view seemingly puts stakeholderism on higher moral ground. Jensen (2001), an avid shareholderist, refers to corporate strategy that considers other stakeholders as "enlightened value maximization" (see also Sundaram \& Inkpen, 2004). In the United Kingdom, imposing a legal duty of "enlightened shareholder value" was one of the most hotly debated provisions of the Companies Act, 2006 (Keay, 2007).

This study sheds new light on this discourse as it shows that both shareholderism and stakeholderism are linked with basic universal values that reflect desirable motivational goals: shareholderism - with achievement and self-direction; stakeholderism - with 
universalism. Proponents of both stances thus may find support for their views in broad conceptions of the desirable. However, across many samples, benevolence and universalism values are consistently ranked among the most important, while power values often rank among the least important (Schwartz \& Bardi, 2001). It may be the case that individuals who, relative to others, are high on power and endorse shareholderism may nonetheless acknowledge the importance of universalism and, therefore, acknowledge the legitimacy of its logical correlate - stakeholderism.

Legal scholars have discussed the Credit Lyonnais case in the context of the shareholder-stakeholder debate (Blair \& Stout, 1999; Macey \& Miller, 1993). However, the respective vignette did not load on the shareholderism factor, while the vast majority of all board members sided with the creditors. Participants may have interpreted this vignette as a case of firm survival, in which all parties may need to shoulder the effort to keep the firm alive. These results are consistent with the idea that board members might agree with the dictum in Credit Lyonnais, that in the zone of insolvency, board members may have a duty to consider the interests of the corporate enterprise and not only of shareholders.

In the absence of better remedies, these days independent directors are regularly touted as panacea to current ills of corporate governance - in particular, the need to monitor corporate insiders. Independence here means lack of significant pecuniary or personal linkage to the company and its insiders. The current findings suggest that directors might formally satisfy regulatory criteria for independence but may nonetheless approach strategic issues differently depending on their personal attributes and background (Jensen \& Zajac, 2004; Hiller \& Hambrick, 2005). The effect of board diversity for strategic management remains a fruitful avenue for research (cf. Adams \& Ferreira, 2009).

Recall the support among board members for adopting a multiple-stakeholder corporate philosophy. Importantly, we find that the tendency to prefer either philosophy 
varies in conjunction with directors' general shareholderism stance. In tandem, Fiss and Zajac (2004) found that many German firms during the 1990s espoused a shareholder value orientation in their annual reports notwithstanding corporate practice and a legal prescription that the firm be managed for the benefit of multiple stakeholders. Fiss and Zajac's (2004) and our results together may suggest a "triple decoupling" of legal prescriptions, corporate espousal, and implementation. The present evidence points to the individual-level mechanism that may be driving such decoupling - namely, the values and roles of corporate elite members and to a lesser extent also their demographics. However, it may also be the case that such broad endorsement may reflect Swedish culture and that in other cultures the average endorsement of a stakeholderist philosophy would be lower.

Standard accounts in comparative corporate governance classify the Anglo-American system as shareholder-oriented and Western European systems as more stakeholder-oriented especially with regard to employees (e.g., Bradley et al., 1999; Roe, 2003). Focal policy documents on corporate governance best principles (e.g., OECD, 2004) generally endorse shareholder primacy, while they often acknowledge the interests of other stakeholders. Although the role of cultural orientations in international business is the subject of a large and diversified literature (see Leung et al., 2005), little was done to associate between culture and shareholderism vs. stakeholderism in national corporate governance systems (see Licht, 2001; Siegel, Licht, \& Schwartz, 2007). As cultural differences are reflected in differences in average value priorities, one would expect to see systematic differences among countries also in directors' shareholderism stances. Such research is clearly warranted in light of the movement for corporate governance reform in many countries.

“Does it pay to be good?” ask Margolis, Elfenbein, and Walsh (2007), and answer that the overall effect of social performance (CSP) on financial performance (CFP) is positive but small. Like many of the authors of the 167 studies that they meta-analyze, Margolis et al. 
find that better CFP associates with better CSP (see also Orlitzki et al., 2003). This evidence, they aver, "should direct our attention equally to understanding how CFP ultimately gives rise to CSP" (pp. 24-25). The current results present a small piece of evidence toward answering this question. The finding, that better financial performance predicts stronger shareholderism, challenges the view that managers in profitable firms would tend to channel resources to CSP, perhaps opportunistically. If anything, higher profitability seems to make directors keener on maximizing shareholder wealth. What makes this finding noteworthy is the fact that it refers to the individual level of analysis. It seems unlikely that a single director's values would affect her firm's financial performance. Something else may be driving CSP, and it may well be directors' values as well as internal (corporate) and/or external (societal) institutional pressures (Brickson, 2005; 2007; Campbell, 2007).

\section{CONCLUSION}

Some ninety years have passed since the Michigan Supreme Court famously admonished

Henry Ford and the entire business community for years to come:

A business corporation is organized and carried on primarily for the profit of the stockholders. The powers of the directors are to be employed for that end. The discretion of directors is to be exercised in the choice of means to attain that end and does not extend to a change in the end itself, to the reduction of profits or to the nondistribution of profits among stockholders in order to devote them to other purposes. (Dodge v. Ford, 1919: 683).

Ford, a quintessential capitalist, thought otherwise:

I don't believe we should make such an awful profit on our cars. A reasonable profit is right, but not too much. I hold that it is better to sell a large number of cars at a reasonable small profit... I hold this because it enables a larger number of people to buy and enjoy the use of a car and because it gives a larger number of men employment at good wages. Those are the aims I have in life (Nevins \& Hill, 1957: 97).

Ninety years and reams of paper later, and the likelihood of resolving this debate seems as remote as ever. Plus ça change, plus c'est la même chose. The findings of this 
study suggest that these controversies may never be resolved, as they are rooted in the most basic beliefs that people hold about their goals in life.

\section{Acknowledgments}

We are grateful to Jan Bertil Andersson, Rolf Dotevall, and Rolf Skog for invaluable advice on Swedish corporate law and to Anders Karlsson for able research assistance. Adams thanks SNS Centre for Business and Policy Studies and the Jan Wallander and Tom Hedelius Research Foundation for funding the data collection for this project. Licht gratefully acknowledges Israel Science Foundation Grant No. 342/08. Sagiv's research was supported by a grant from the Recanatti Fund of the School of Business Administration at the Hebrew University. 


\section{TABLES}

Table 1. The Schwartz Individual-Level Values and Representative Items

\begin{tabular}{|l|l|}
\hline Security & $\begin{array}{l}\text { Safety, harmony and stability of society, of relationships and of self (family } \\
\text { security, national security, social order, clean, reciprocation of favors) }\end{array}$ \\
\hline Conformity & $\begin{array}{l}\text { Restraint of actions, inclinations and impulses likely to upset or harm others } \\
\text { and violate social expectations or norms (self-discipline, obedient, politeness, } \\
\text { honoring parents and elders) }\end{array}$ \\
\hline Tradition & $\begin{array}{l}\text { Respect, commitment and acceptance of the customs and ideas that traditional } \\
\text { culture or religion provide (accepting my portion in life, humble, devout, } \\
\text { respect for tradition, moderate) }\end{array}$ \\
\hline Benevolence & $\begin{array}{l}\text { Preservation and enhancement of the welfare of people whom one is in } \\
\text { frequent personal contact (helpful, honest, forgiving, loyal, responsible) }\end{array}$ \\
\hline Universalism & $\begin{array}{l}\text { Understanding, appreciation, tolerance and protection for the welfare of all } \\
\text { people and for nature (broadminded, wisdom, social justice, equality, a world } \\
\text { at peace, a world of beauty, unity with nature, protecting the environment) }\end{array}$ \\
\hline Self-Direction & $\begin{array}{l}\text { Independent thought and action-choosing, creating, exploring (creativity, } \\
\text { freedom, independent, curious, choosing own goals) }\end{array}$ \\
\hline Stimulation & Excitement, novelty and challenge in life (daring, a varied life, an exciting life) \\
\hline Hedonism & Pleasure and sensuous gratification for oneself (pleasure, enjoying life) \\
\hline Achievement & $\begin{array}{l}\text { Personal success through demonstrating competence according to social } \\
\text { standards (successful, capable, ambitious, influential) }\end{array}$ \\
\hline Power & $\begin{array}{l}\text { Social status and prestige, control or dominance over people and resources } \\
\text { (social power, authority, wealth) }\end{array}$ \\
\hline
\end{tabular}


Table 2. Summary Statistics and Correlation Matrix

\section{A. Board Member Variables}

\begin{tabular}{|c|c|c|c|c|c|c|c|c|c|c|c|c|c|c|c|c|c|c|c|c|c|}
\hline & Variable & Obs & Mean & Std. Dev. & Min & $\operatorname{Max}$ & (1) & (2) & (3) & (4) & (5) & (6) & (7) & (8) & (9) & $(10)$ & (11) & (12) & (13) & (14) & (15) \\
\hline (1) & Security & 628 & 3.714 & 0.802 & 1.00 & 5.80 & & & & & & & & & & & & & & & \\
\hline (2) & Conformity & 628 & 3.492 & 0.897 & 1.00 & 6.00 & $.570^{* *}$ & & & & & & & & & & & & & & \\
\hline (3) & Tradition & 628 & 2.521 & 0.637 & 1.00 & 4.75 & $.414 * *$ & $.545^{* *}$ & & & & & & & & & & & & & \\
\hline (4) & Benevolence & 628 & 4.334 & 0.725 & 1.00 & 6.00 & $.258^{* *}$ & $.275^{* *}$ & $.207^{* *}$ & & & & & & & & & & & & \\
\hline (5) & Universalism & 628 & 4.155 & 0.760 & 1.00 & 6.00 & $.238 * *$ & $.221 * *$ & $.199 * *$ & $.558^{* *}$ & & & & & & & & & & & \\
\hline (6) & Self-Direction & 628 & 4.681 & 0.721 & 1.00 & 6.00 & .033 & $-.080 *$ & $-.125 * *$ & $.259^{* *}$ & $.236^{* *}$ & & & & & & & & & & \\
\hline (7) & Stimulation & 628 & 3.641 & 0.993 & 1.00 & 6.00 & -.047 & -.024 & -.044 & $.241 * *$ & $.201 * *$ & $.532 * *$ & & & & & & & & & \\
\hline (8) & Hedonism & 628 & 3.737 & 1.058 & 1.00 & 6.00 & $.200^{* *}$ & $.211^{* *}$ & $.134 * *$ & $.249^{* *}$ & $.169^{* *}$ & $.269^{* *}$ & $.432 * *$ & & & & & & & & \\
\hline (9) & Achievement & 628 & 3.788 & 0.834 & 1.00 & 6.00 & $.236 * *$ & $.160 * *$ & -.004 & $.069^{*}$ & -.036 & $.349 * *$ & $.293 * *$ & $.262 * *$ & & & & & & & \\
\hline (10) & Power & 628 & 3.327 & 0.834 & 1.00 & 5.67 & $.219^{* *}$ & $.163^{* *}$ & .057 & -.031 & $-.107 * *$ & $.290 * *$ & $.248^{* *}$ & $.302^{* *}$ & $.614 * *$ & & & & & & \\
\hline (11) & $\mathrm{CEO}$ & 628 & 0.20 & 0.400 & 0.00 & 1.00 & .031 & -.057 & .026 & -.060 & -.046 & .052 & .029 & .000 & $.145^{* *}$ & $.164 * *$ & & & & & \\
\hline (12) & Employee Rep. & 628 & 0.20 & 0.400 & 0.00 & 1.00 & $.130 * *$ & $.197 * *$ & .047 & $.091^{*}$ & $.189^{* *}$ & $-.198 * *$ & $-.184 * *$ & .034 & $-.241^{* *}$ & $-2.35^{* *}$ & $-.252 * *$ & & & & \\
\hline (13) & Age & 628 & 54.28 & 9.155 & 25.00 & 74.00 & -.001 & -.009 & .055 & $-.079 *$ & -.055 & -.033 & -.064 & $-.188 * *$ & -.078 & -.001 & $-.201 * *$ & $-.162 * *$ & & & \\
\hline (14) & Gender & 628 & 0.83 & 0.375 & 0.00 & 1.00 & .072 & $.080^{*}$ & $.092 *$ & $-.173^{* *}$ & $-.186^{* *}$ & -.016 & -.042 & -.017 & $.081^{*}$ & $.156^{* *}$ & $.173^{* *}$ & $-.165^{* *}$ & $.158^{* *}$ & & \\
\hline (15) & \# Directorships & 628 & 2.00 & 1.443 & 1.00 & 7.00 & .033 & .007 & .065 & .000 & $.088^{*}$ & .010 & .031 & -.043 & .007 & -.033 & -.045 & $-.117 * *$ & $.155^{* *}$ & .004 & \\
\hline (16) & Tenure & 627 & 3.05 & 2.270 & 0.00 & 9.00 & -.025 & -.007 & -.004 & -.040 & -.013 & .030 & .013 & -.014 & .015 & .032 & $-.186^{* *}$ & $-.086^{*}$ & $.162 * *$ & -.002 & $.147^{* *}$ \\
\hline
\end{tabular}

**, * significant at $1 \%, 5 \%$.

\section{B. Firm Variables}

\begin{tabular}{llllllll}
\hline \multicolumn{1}{r}{ Variable } & \multicolumn{1}{c}{ Obs } & \multicolumn{1}{c}{ Mean } & \multicolumn{1}{c}{ Std. Dev. } & \multicolumn{1}{c}{ Min } & \multicolumn{1}{c}{ Max } & (1) & (2) \\
\hline (1) Return on Assets & 595 & -0.01 & 0.151 & -0.23 & 0.36 & & \\
(2) Total Wage Bill & 591 & 146286756.35 & 516253756.24 & 0.00 & 4880000000.00 & $.186^{* *}$ & \\
(3) Firm Assets (ln) & 595 & 20.46 & 2.03 & 14.62 & 26.09 & $.349^{* *}$ & $.309^{* *}$ \\
\hline
\end{tabular}

**, * significant at $1 \%, 5 \%$. 
Table 3. Correlations between Values and Shareholderism

\begin{tabular}{lc}
\hline & Shareholderism \\
\hline Security & $-.09 *$ \\
Conformity & $-.11 * *$ \\
Tradition & $-.12 * *$ \\
Benevolence & $-.19 * *$ \\
Universalism & $-.35 * *$ \\
Self-Direction & $.20 * *$ \\
Stimulation & $.14 * *$ \\
Hedonism & .03 \\
Achievement & $.34 * *$ \\
Power & $.35 * *$ \\
\hline$N$ & 621 \\
\hline
\end{tabular}

One-tailed Pearson correlations. Value priorities scores are controlled for mean rating. **, * significant at $1 \%, 5 \%$. 
Table 4. Regressions of Directors' Shareholderism on Values, Roles, and Other Factors

\begin{tabular}{|c|c|c|c|c|c|}
\hline & (1) & (2) & (3) & (4) & (5) \\
\hline \multirow[t]{2}{*}{ Power } & $0.17 * *$ & $0.23 * *$ & $0.11 * *$ & $0.12 *$ & $0.12 *$ \\
\hline & {$[0.05]$} & {$[0.07]$} & {$[0.05]$} & {$[0.06]$} & {$[0.07]$} \\
\hline \multirow[t]{2}{*}{ Self-Direction } & $0.16 * *$ & $0.13 * *$ & $0.07 *$ & $0.07 *$ & $0.08 *$ \\
\hline & {$[0.05]$} & {$[0.06]$} & {$[0.05]$} & {$[0.05]$} & {$[0.05]$} \\
\hline \multirow[t]{2}{*}{ Achievement } & $0.15 * *$ & $0.21 * *$ & $0.08+$ & $0.10 *$ & $0.11 *$ \\
\hline & {$[0.06]$} & {$[0.07]$} & {$[0.05]$} & {$[0.06]$} & {$[0.06]$} \\
\hline \multirow[t]{2}{*}{ Universalism } & $-0.18 * *$ & $-0.18 * *$ & $-0.15 * *$ & $-0.12 * *$ & $-0.11 *$ \\
\hline & {$[0.08]$} & {$[0.08]$} & {$[0.07]$} & {$[0.07]$} & {$[0.07]$} \\
\hline \multirow[t]{2}{*}{ Entrepreneurship } & & $0.12+$ & & 0.04 & 0.05 \\
\hline & & {$[0.08]$} & & {$[0.08]$} & {$[0.08]$} \\
\hline \multirow[t]{2}{*}{ Employee Representative } & & & $-0.44 * *$ & $-0.42 * *$ & $-0.43 * *$ \\
\hline & & & {$[0.08]$} & {$[0.08]$} & {$[0.10]$} \\
\hline \multirow[t]{2}{*}{ Gender (male) } & & & & $0.16 * *$ & $0.18 * *$ \\
\hline & & & & {$[0.08]$} & {$[0.09]$} \\
\hline \multirow[t]{2}{*}{ Age } & & & & $-0.08 *$ & $-0.07 *$ \\
\hline & & & & {$[0.00]$} & {$[0.00]$} \\
\hline \multirow[t]{2}{*}{ CEO } & & & & -0.03 & -0.04 \\
\hline & & & & {$[0.07]$} & {$[0.08]$} \\
\hline \multirow[t]{2}{*}{ Tenure } & & & & $0.07 *$ & 0.03 \\
\hline & & & & {$[0.01]$} & {$[0.01]$} \\
\hline \multirow[t]{2}{*}{ \# Directorships } & & & & $0.10 * *$ & $0.08 * *$ \\
\hline & & & & {$[0.03]$} & {$[0.03]$} \\
\hline \multirow[t]{2}{*}{ Return on Assets } & & & & & $0.07 *$ \\
\hline & & & & & {$[0.16]$} \\
\hline \multirow[t]{2}{*}{ Firm Wage Bill (ln) } & & & & & 0.00 \\
\hline & & & & & {$[0.00]$} \\
\hline \multirow[t]{2}{*}{ Firm Assets (ln) } & & & & & 0.04 \\
\hline & & & & & {$[0.02]$} \\
\hline Observations & 626 & 626 & 626 & 626 & 564 \\
\hline R-squared & 0.21 & 0.21 & 0.37 & 0.41 & 0.42 \\
\hline
\end{tabular}

Dependent variable: shareholderism stances (higher scores reflect higher shareholderism).

Standardized beta coefficients. Robust standard errors, clustered at firm level, are in brackets. $* *, *,+$ significant at $1 \%, 5 \%, 10 \%$. 


\section{FIGURES}

Figure 1. Responses to the Vignettes
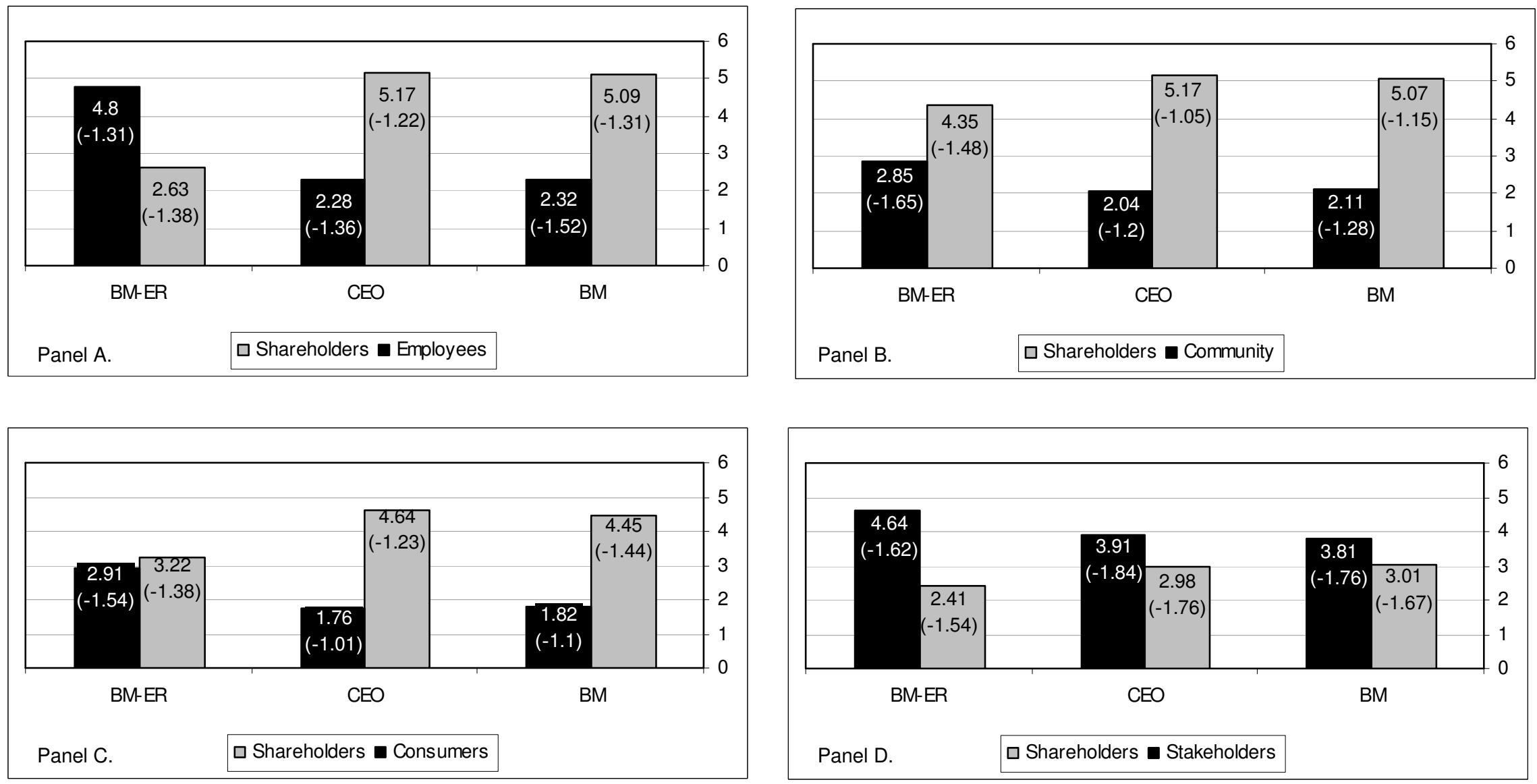


\section{REFERENCES}

Adams, R.B., \& Ferreira, D. 2007. A theory of friendly boards. Journal of Finance, 62: 217250.

Admas, R.B. \& Ferreira, D. 2009. Women in the boardroom and their impact on governance and performance, Journal of Financial Economics forthcoming.

Agle, B.R., \& Caldwell, C.B. 1999. Understanding research on values in business, Business and Society, 38: 326-387.

Agle, B.R., Mitchell, R.K., \& Sonnenfeld, J.A. 1999. Who matters to CEOs? An investigation of stakeholder attributes and salience, corporate performance, and CEO values. Academy of Management Journal, 42: 507-25.

Agle, B.R., Mitchell, R.K., \&. Sonnenfeld, J.A 1999. Who Matters to CEOs? An investigation of stakeholder attributes and salience, corporate performance, and CEO values. Academy of Management Journal, 42: 507-525.

Alexander, C. S., \& Becker, H. J.1978. The use of vignettes in survey research, Public Opinion Quarterly, 42: 93-104.

Bardi, A., \& Schwartz, S. H. 2003. Values and behavior: Strength and structure of relations. Personality and Social Psychology Bulletin, 29: 1207-1220.

Barnea, M., \& Schwartz, S.H. 1998. Values and voting. Political Psychology, 19: 17-40.

Barnett, J. H., \& Karson, M.J. 1987. Personal values and. business decisions: An exploratory investigation. Journal of Business Ethics, 6: 371-382.

Barnett, J., \& Karson, M. 1989. Managers, values, and executive decisions: An exploration of the role of gender, career stage, organizational level, function, and the importance of ethics, relationships and results in managerial decision making. Journal of Business Ethics, 8: 747-771.

Barnett, M.L., \& Salomon, R.M. 2006. Beyond dichotomy: The curvilinear relationship between social responsibility and financial performance. Strategic Management Journal, 27: 1101-1112.

Barter, C., \& Renold, E. 1999. The use of vignettes in qualitative research. Social Research Update, 25. http://www.soc.surrey.ac.uk/sru/SRU25.html

Berglöf, E., \& von Thadden, E.L. 2000. The changing corporate governance paradigm: Implications for transition and developing countries. In B.Pleskovic \& J. Stiglitz (Eds.), World Development Conference 135-151. Washington, DC: World Bank.

Berle, A.A., 1932. For whom corporate managers are trustees. Harvard Law Review, 45: 1365-1372.

Berle, A.A., \& Means, G.C. 1932. The modern corporation and private property. (Rev. ed.). New Brunswick, NJ: Transaction Publishing.

Bertrand, M., \& Mullainathan, S. 2003. Enjoying the quiet life? Corporate governance and managerial preferences. Journal of Political Economy, 111: 1043-1075.

Bitler, M, Moskowitz, TJ, \& Vissing-Jurgensen, A. 2005. Testing agency theory with entrepreneur effort and wealth. Journal of Finance, 60: 539-576.

Blair, M.M., \& Stout, L.A. 1999. A team production theory of corporate law. Virginia. Law Review, 85: 247-328.

Bosse, D., Phillips, R. \& Harrison, J. 2009. Stakeholders, reciprocity and firm performance. Strategic Management Journal, 30(4): 447-456.

Bradley, M., Schipani, C. A., Sundaram A. K., \& Walsh J. P. 1999. The purposes and accountability of the corporation in contemporary society: Corporate governance at a crossroads. Law and Contemporary Problems, 62: 9-86.

Brickson, S. L. 2005. Organizational identity orientation: Forging a link between organizational identity and organizations' relations with stakeholders. Administrative 
Science Quarterly, 50: 576-609.

Brickson, S. L. 2007. Organizational identity orientation: The genesis of the role of the firm and distinct forms of social value. Academy of Management Review, 32: 864-888.

Campbell, J. L. 2007. Why would corporations behave in socially responsible ways? An institutional theory of corporate social responsibility. Academy of Management Review, 32: 946-967.

Caprara, G.V., \& Steca, P. 2007. Prosocial agency: The contribution of values and selfefficacy beliefs to prosocial behavior across ages. Journal of Social and Clinical Psychology, 26: 218-239.

Caprara, G.V., Schwartz, S.H., Cabaña, C., Vaccine, M., \& Barbaranelli, C. 2006. Personality and politics: Values, traits, and political choice. Political. Psychology, 27: 128.

Choi, J., \& Wang, H. 2009. Stakeholder relations and the persistence of corporate financial performance. Strategic Management Journal, 30(8): 895-907.

Code Group, 2005. Swedish Code of Corporate Governance. Stockholm: Swedish Government Official Reports.

Connor, P.E., \& Becker, B.W. 1994. Personal values and management: What do we know and why don't we know more? Journal of Management Inquiry, 3: 67-73.

Credit Lyonnais Bank Nederland N.V. v. Pathé Communications, 19911991 WL 277613 (Del. Ch.).

de Bakker, F. G. A., Groenewegen, P., \& den Hond, F. 2005. A bibliometric analysis of 30 years of research and theory on corporate social responsibility and corporate social performance. Business \& Society, 44: 283-317.

DellaVigna, S. 2008. Psychology and economics: Evidence from the field. Journal of Economic Literature, forthcoming.

Dodd, E.M. 1932. For whom are corporate managers trustees? Harvard Law Review, 45: $1145-1163$.

Dodge v. Ford Motor Co., 1919170 N.W. 668.

Donaldson, T., \& Preston, L. 1995. The stakeholder theory of the corporation: Concepts, evidence, and implications. Academy of Management Review, 20: 65-91.

Easterbrook, F., \& Fischel, D. 1991. The Economic Structure of Corporate Law. Cambridge, MA: Harvard University Press.

England, G. W. 1967. Personal value systems of American managers. Academy of Management Journal, 10: 53-68.

Fagenson, E.A. 1993. Personal value systems of men and women entrepreneurs versus managers. Journal of Business Venturing, 8: 409-430.

Faleye, O., Mehrotra, V., \& Morck, R. 2006. When labor has a voice in corporate. governance. Journal of Financial and Quantitative Analysis, 41: 489-510.

Feather, N.T. 1995, Values, valence, and choice: The influence of values on perceived attractiveness and choices of alternatives. Journal of Personality and Social Psychology, 65: $1135-1151$.

Fiss, P.C. \& Zajac, E. 2004. The diffusion of ideas over contested terrain: The (non)adoption of a shareholder value orientation in German firms. Administrative Science Quarterly, 49(4): 501-534.

Finch, J. 1987. The vignette technique in survey research. Sociology, 21: 105-114.

Frederick, W.C. 1995. Values, Nature, and Culture in the American Corporation. Oxford: Oxford University Press.

Freeman, R.E. 1984. Strategic Management: A Stakeholder Approach. Boston: Pitman.

Friedman, M. 1970. The social responsibility of business is to increase its profits. New York Times Magazine (September 13) 33: 122-126. 
Gandal, N., Roccas, S., Sagiv, L., \& Wrzesniewski A. 2005. Personal value priorities of economists. Human Relations, 58: 1227-1252.

Glen, N. D. 1974, Aging and conservatism, Annuals of the American Academy of Political and Social Science, 415: 176-186.

Godfrey, P.C., Craig G.M., \& Jared M.H. 2009. The Relationship Between Corporate Social Responsibility and Shareholder Value: An Empirical Test of the Risk Management Hypothesis, Strategic Management Journal 30(4): 425-445.

Goodnow, J. J. 1997. Parenting and the transmission and internalization of values: From social-cultural perspectives to within-family analyses. In: J. E. Grusec \& L. Kuczynski (Eds.), Parenting and Children's Internalization of Values: A Handbook of Contemporary Theory, 333-361. New York: Wiley.

Grunert, S.C. \& Juhl, H.J. 1995. Values, environmental attitudes, and buying organic foods. Journal of Economic Psychology, 16: 39-62.

Guth, W.D., \& Tagiuri, R. 1965. Personal values and corporate strategies. Harvard Business Review, 43: 123-124.

Hambrick, D., \& Mason, P. 1984. Upper echelons: The organization as a reflection of its top managers. Academy of Management Review, 9: 193-206.

Hart, O. 1993. An economist's view of fiduciary duty. University of Toronto Law Journal, 43: 299-313.

Hemingway, C.A., \& Maclagan, P.W. 2004. Managers personal values as drivers of corporate social responsibility. Journal of Business Ethics, 50: 33-44.

Hemingway, C.A. 2005. Personal values as a catalyst for corporate social entrepreneurship. Journal of Business Ethics, 60: 233-249.

Hiller, N.J. \& Hambrick, D.C. 2005. Conceptualizing executive hubris: The role of (hyper-) core self-evaluations in strategic decision-making. Strategic Management Journal, 26: 297-319.

Hitlin, S. 2003. Values as the core of personal identity: drawing links between two theories of self. Social Psychology Quarterly, 66: 118-137.

Hitlin, S., \& Piliavin, J.A. 2004, Values: Reviving a dormant concept. Annual Review of Sociology, 30: 359-93.

Ibrahim, N.A., Howard, D.P., \& Angelidis, J.P. 2003. Board members in the service industry: An empirical examination of the relationship between corporate social responsibility orientation and directorial type. Journal of Business Ethics, 47: 393-401

Jensen M. C. 2001. Value maximization, stakeholder theory, and the corporate objective function. European Financial Management, 7: 297-317.

Jensen M., \& Meckling W. 1976. The theory of the firm: Managerial behavior, agency costs, and ownership structure. Journal of Financial Economics, 18: 305-360.

Jensen, M., \& Zajac, E. J. 2004. Corporate elites and corporate strategy: How demographic preferences and structural position shape the scope of the firm. Strategic Management Journal, 25(6): 507-524.

Keay, A. 2007. Tackling the issue of the corporate objective: An analysis of the united kingdom's 'enlightened shareholder value approach. Sydney Law Review, 29: 577-612.

Kirzner, I. 1973. Competition and Entrepreneurship. Chicago: University of Chicago Press.

Kluckhohn, C. K. 1951. Values and value orientations in the theory of action. In: T. Parsons $\&$ E. A. Shils (Eds.). Toward a General Theory of Action. 388-433. Cambridge, MA: Harvard University Press.

Knafo, A., \& Schwartz, S. H. 2004. Identity formation and parent-child value congruence in adolescence. British Journal of Developmental Psychology, 22: 439-458.

Knight, F. H. 1921. Risk, Uncertainty, and Profit. Boston, MA: Houghton Mifflin.

Kossowska, M., Van Hiel, A.,. Chun, W.Y., \& Kruglanski, A.W. 2002. The need for 
cognitive closure scale: structure, cross-cultural invariance, and comparison of mean ratings between European-American and East Asian samples. Psychologica Belgica, 42: 276-286.

Leung, K., Bhagat, R.S., Buchan, N.R., Erez, M., \& Gibson, C.B. 2005. Culture and international business: Recent advances and their implications for future research. Journal of International Business Studies, 36: 357-378.

Levinson, K. 2001. Employee representatives on company boards in sweden. Industrial Relations Journal, 32(3): 264-274.

Licht, A.N. 2004. The maximands of corporate governance: A theory of values and cognitive style. Delaware Journal of Corporate Law, 29: 649-746.

Licht, A.N. 2007. The entrepreneurial spirit and what the law can do about it. Comparative Labor Law \& Policy Journal, 28: 817-861.

Lincoln, D. J., Pressley, M.M., \& Little, T. 1982. Ethical beliefs and personal values of top level executives. Journal of Business Research, 10: 475-487.

Lorsch, JW, MacIver, E. 1989. Pawns or Potentates: The Reality of America's Corporate Boards. Harvard Business School, Boston, MA.

Macey, J.R. \& Miller, G.P. 1993. Corporate stakeholders: A contractual perspective. University of Toronto Law Journal, 43: 401-424.

Margolis, J. D., Elfenbein, H. A., \& Walsh, J. P. 2007. Does it pay to be good? A metaanalysis and redirection of research on the relationship between corporate social and financial performance. Working paper, Harvard Business School, Boston, MA.

Margolis, J. D., \& Walsh, J. P. 2003. Misery loves companies: Rethinking social initiatives by business. Administrative Science Quarterly, 48: 268-305.

McFadden, D. L. et al. 2005. Statistical analysis of choice experiments and surveys. Marketing Letters, 16: 183-196.

Meglino, B. M., \& Ravlin, E. C. 1998. Individual values in organizations: Concepts, controversies, and research. Journal of Management, 24: 351-389.

Mitchell, R. et al. 2007. The central question in entrepreneurial cognition research 2007. Entrepreneurship Theory and Practice, 31: 1-27.

Mitchell, R.K., Agle, B.R., \& Wood, D.J. 1997. Toward a theory of stakeholder identification and salience: Defining the principle of who and what really counts. Academy of Management Review, 22: 853-886.

Nevins, A. \& Hill, F. 1957. Ford: Expansion and Challenge: 1915-1933. New York: Scribner.

Noseleit, F. 2008. The Entrepreneurial culture. Guiding principles of self-employed. In: Freytag, A. \& Thurik, R. (Eds.), Entrepreneurship and Culture. Berlin: Springer (forthcoming).

Oliver, B. 1999. Comparing corporate managers' personal values over three. decades, 19671995. Journal of Business Ethics, 20: 147-161.

Organisation for economic co-operation and development. 2004. OECD Principles of Corporate Governance, http://www.oecd.org/dataoecd/32/18/31557724.pdf.

Orlitzky M., Schmidt, F. L., \& Rynes S. 2003. Corporate social and financial performance: A meta-analysis. Organization Studies, 24: 403-411.

Orts, E. 1992. Beyond shareholders: Interpreting corporate constituency statutes. George Washington Law Review, 14: 14-135.

Pagano, M., \& Volpin, P. 2005. Managers, workers, and corporate control. Journal of Finance, 60: 843-870.

Papadakis, V.M., Lioukas, S., \& Chambers, D. 1998. Strategic decision-making processes: the role of management and context, Strategic Management Journal, 19: 115-147.

Parke v. Daily News Ltd. 1962. [1962] Ch 927. 
Payne, J. W., Bettman, J. R., \& Johnson, E.1993. The Adaptive Decision Maker. Cambridge, UK: Cambridge University Press.

Posner, B. Z., \& Schmidt, W. H. 1992. Values and the American manager: An update updated. California Management Review, 34: 80-94.

Roccas, S., Sagiv, L., Schwartz, S. H., \& Knafo, A. 2002. The Big Five personality factors and personal values. Personality and Social Psychology Bulletin, 28: 789-801.

Roe, M.J. 2003. Political Determinants of Corporate Governance. Oxford: Oxford University Press.

Rohan, M.J. 2000. A rose by name? The values construct. Personality and Social Psychology Review, 4: 255-277.

Rokeach, M. 1973. The Nature of Human Values. New York, NY: The Free Press.

Sagiv, L., \& Schwartz. S.H. 2004. Values, intelligence and client behavior in career counseling: A field study. European Journal of Education \& Psychology, 19: 237-254.

Sattler, D.N., \& Kerr, N.L. 1991. Might versus morality explored: Motivational and cognitive bases for social motives. Journal of Personality and Social Psychology, 60: 756-765.

Schneider, B., Goldstein, H. W., \& Smith, D. B. 1995. The ASA framework: An update. Personnel Psychology, 48: 747-773.

Schneider, S. C., Oppegaard, K., Zollo, M., \& Huy, Q. 2005. Socially responsible behavior: Developing virtue in organizations. Working paper, INSEAD, Paris.

Schumpeter, J. A. 1912/1934. The theory of economic development. Cambridge, MA: The Harvard University Press.

Schwartz, S.H. 1992. Universals in the content and structure of values: Theory and empirical tests in 20 countries. In: M. Zanna (Ed.), Advances in Experimental Social Psychology 25: 1-65. New York: Academic Press.

Schwartz, S.H. 2007. Value orientations: Measurement, antecedents and consequences across nations. In: R. Jowell, C. Roberts, R. Fitzgerald \& G. Eva, (Eds.), Measuring Attitudes Cross-Nationally - Lessons from the European Social Survey. London: Sage.

Schwartz, S.H. 2009. Basic values: How they motivate and inhibit prosocial behavior. In: M. Mikulincer \& P. Shaver (Eds.), Herzliya Symposium on Personality and Social Psychology, Vol.1. Washington: American Psychological Association Press.

Schwartz, S. H., \& Rubel, T. 2005. Sex differences in value. Priorities: cross-cultural and multimethod studies. Journal of Personality and Social Psychology, 89: 1010-1028.

Schwartz, S. H., Sagiv, L., \& Boehnke, K. 2000. Worries and Values. Journal of Personality, 68: 309-346.

Schwartz, S.H. et al. 2001. Extending the cross-cultural validity of the theory of basic human values with a different method of measurement. Journal of Cross Cultural Psychology, 32: 519-542.

Shafer, W.E., Fukukawa, K., \& Lee, G. M. 2007. Values and the perceived importance of ethics and social responsibility: The U.S. versus China. Journal of Business Ethics, 70: 256-284.

Shlensky v.Wrigley 1968237 N.E.2d 776 (Ill. App.)

Siegel, J.I., Licht, A.N., \& Schwartz, S.H. 2007. Egalitarianism and International Investment. Working paper. http://ssrn.com/abstract=899082.

Smith, D.G. 1998. The shareholder primacy norm. Journal of Corporation Law, 23: 277323.

Smith, P.B., Bond, M.H., Kagitcibasi, C. 2006. Understanding social psychology across Cultures. 3rd edition. London: Sage.

Sobel, J. 2005. Interdependent preferences and reciprocity. Journal of Economic Literature, 43: 392-436. 
Tetlock, P.E. 2000. Cognitive biases and organizational correctives: Do both disease and cure depend on the ideological beholder? Administrative Science Quarterly, 45: 293-326.

Van Lange, P.A.M., \& Liebrand, W.B.G. 1991. The influence of other's morality and own social value orientation on cooperation in the Netherlands and the U.S.A. International Journal of Psychology, 26: 429-449.

Van Praag, C. M. 1999. Some Classic views on entrepreneurship. De Economist, 147: 311335.

Verplanken, B., \& Holland, RW. 2002. Motivated decision-making: effects of activation and self-centrality of values on choices and behavior. Journal Personality and Social Psychology, 82: 434-447.

Victorin, A. 2000. Employee participation on the company board. The Swedish experience, in Company Law Reform in OECD Countries: A Comparative Outlook of Current Trends, Stockholm.

Waddock, S., \& Graves, S. 1997. The corporate social performance-financial performance linkage. Strategic Management Journal, 18(4): 303-319.

Wason, K., Polonsky, M., \& Hyman, M. 2002. Designing vignette studies in marketing. Australasian Marketing Journal, 10(3): 41-58.

Webster, D. M., \& Kruglanski, A. W. 1994. Individual differences in need for cognitive closure. Journal of Personality and Social Psychology, 67: 1049-1062.

Westphal, J. \& Zajac, E. 2001. Decoupling policy from practice: the case of stock repurchase programs, Administrative Science Quarterly, 46: 202-228. 